\begin{tabular}{cc|c}
\hline Tar. Bil. Der. & Tarım Bilimleri Dergisi & Journal of Agricultural Sciences \\
& $\begin{array}{c}\text { Dergi web sayfası: } \\
\text { www.agri.ankara.edu.tr/dergi }\end{array}$ & Journal homepage: \\
& www.agri.ankara.edu.tr/journal
\end{tabular}

\title{
Effect of NaCl Stress on Chlorophyll Biosynthesis, Proline, Lipid Peroxidation and Antioxidative Enzymes in Leaves of Salt-Tolerant and Salt-Sensitive Barley Cultivars
}

\author{
Mustafa YILDIZ ${ }^{\mathrm{a}}$, Hakan TERZİ \\ a Afyon Kocatepe University, Faculty of Science and Literature, Department of Biology, Afyonkarahisar, TURKEY
}

\section{ARTICLE INFO}

Research Article - Crop Production ～https://doi.org/10.1501/Tarimbil_0000001232

Corresponding Author: Mustafa YILDIZ, E-mail: mustafa_yildizus@yahoo.com, Tel: +90 (272) 2281339

Received: 24 November 2011, Received in Revised Form: 09 May 2013, Accepted: 18 May 2013

\begin{abstract}
In this research, the salt tolerance of salt-tolerant (Avc1-2002) and salt-sensitive (Tokak 157/37) barley cultivars were analyzed. The seedlings were grown in a hydroponic culture containing 0, 100, 200 and $300 \mathrm{mM} \mathrm{NaCl}$. The decrease in dry weight was more significant in Tokak 157/37 than in Avc1-2002. On the other hand, no significant correlations were found between the altered $\delta$-aminolevulinic acid dehydratase (ALAD) activity and the chlorophyll content. The chlorophyll and carotenoid contents in leaves of Avc1-2002 decreased significantly at only $300 \mathrm{mM} \mathrm{NaCl}$, whereas the pigment contents of Tokak 157/37 decreased at all $\mathrm{NaCl}$ concentrations. The increase in proline content was significantly higher in Avc1-2002 than in Tokak 157/37 at $300 \mathrm{mM} \mathrm{NaCl}$. The lipid peroxidation level measured in terms of malondialdehyde (MDA) content was higher in Tokak 157/37 than in Avc1-2002. Salt stress caused significant increases in superoxide dismutase (SOD), guaiacol peroxidase (POD), ascorbate peroxidase (APX) and catalase (CAT) activity. However, Avc1-2002 had relatively lower SOD and CAT activities and higher POD and APX activities than Tokak 157/37. As a result, dry weight, pigments content, proline content, lipid peroxidation and activities of POD and APX results are in good correlation with supporting Avc1-2002 being relatively salt-tolerant.
\end{abstract}

Keywords: Barley; Chlorophyll biosynthesis; Proline; Lipid peroxidation; Antioxidant enzymes; Salt tolerance

\section{Tuza-Toleranslı ve Tuza-Hassas Arpa Çeşitlerinin Yapraklarında Klorofil Biyosentezi, Prolin, Lipit Peroksidasyonu ve Antioksidant Enzimler Üzerine NaCI Stresinin Etkisi}

\section{ESER BİLGÍSI}

Araştırma Makalesi - Bitkisel Üretim

Sorumlu Yazar: Mustafa YILDIZ, E-posta: mustafa_yildizus@yahoo.com, Tel: +90 (272) 2281339

Geliş Tarihi: 24 Kasım 2011, Düzeltmelerin Gelişi: 09 Mayıs 2013, Kabul: 18 Mayıs 2013 


\section{ÖZET}

$\mathrm{Bu}$ araştırmada, tuza toleranslı (Avc1-2002) ve tuza hassas (Tokak 157/37) arpa çeşitlerinin tuza toleransları analiz edilmiştir. Fideler 0, 100, 200 ve $300 \mathrm{mM} \mathrm{NaCl}$ içeren hidroponik kültür ortamında büyütülmüştür. Kuru ağırlıktaki azalma Avc1-2002'ye göre Tokak 157/37 çeşidinde daha önemli bulunmuştur. Diğer taraftan, $\delta$-aminolevülinik asit dehidrataz (ALAD) aktivitesi ve klorofil içeriği arasında önemli korelasyon bulunmamıştır. Avcı-2002 çeşidinin yapraklarında klorofil ve karotenoid içeriği yalnızca $300 \mathrm{mM} \mathrm{NaCl'de} \mathrm{önemli} \mathrm{düzeyde} \mathrm{azalırken,} \mathrm{Tokak} \mathrm{157/37} \mathrm{çeşidinin} \mathrm{pigment}$ içeriği tüm $\mathrm{NaCl}$ konsantrasyonlarında azalmıştır. $300 \mathrm{mM} \mathrm{NaCl}$ konsantrasyonunda, prolin içeriğindeki artış Tokak 157/37 çeşidine göre Avc1-2002 çeşidinde önemli düzeyde daha yüksek bulunmuştur. Malondialdehit (MDA) içeriği ile belirlenmiş lipit peroksidasyon seviyesi Avc1-2002'ye göre Tokak 157/37 çeşidinde daha yüksek bulunmuştur. Tuz stresi süperoksit dismutaz (SOD), guaiakol peroksidaz (POD), askorbat peroksidaz (APX) ve katalaz (CAT) aktivitesinde önemli artışa neden olmuştur. Bununla birlikte, Avcı-2002 çeşidinin Tokak 157/37 çeşidinde göre nispeten daha düşük SOD ve CAT aktivitelerine ve daha yüksek POD ve APX aktivitelerine sahip olduğu belirlenmiştir. Sonuç olarak, kuru ağırlık, pigment içeriği, prolin içeriğii, lipit peroksidasyonu ile POD ve APX aktivite sonuçları nispeten tuza toleranslı Avc1-2002 ile iyi bir korelasyon göstermiştir.

Anahtar Kelimeler: Arpa; Klorofil biyosentezi; Prolin; Lipit peroksidasyonu; Antioksidant enzimler; Tuza tolerans

(C) Ankara Üniversitesi Ziraat Fakültesi

\section{Introduction}

Salinity affects almost every aspect of the physiology and biochemistry of plants and significantly reduces yield. Salt stress leads to a decreased efficiency of photosynthesis and is known to influence the chlorophyll content of plant leaves (Meloni et al 2003). The decrease of chlorophyll synthesis may be due to a decrease of $\delta$-aminolevulinic acid dehydratase (ALAD) activity under environmental stress (Vajpayee et al 2000), but there is no clear information on the behavior of this enzyme in leaves under salt stress conditions. Proline accumulation is one of the adaptations of plants to salinity. It has also been widely advocated that proline accumulation uses as parameter of selection for salt stress tolerance (Ramanjulu \& Sudhakar 2001).

Salinity stress induce enhanced production of the reactive oxygen species (ROS) such as superoxide radicals $\left(\mathrm{O}_{2}{ }^{--}\right)$, singlet oxygen $\left({ }^{1} \mathrm{O}_{2}\right)$, hydroxyl radicals $\left({ }^{\circ} \mathrm{OH}\right)$ and hydrogen peroxide $\left(\mathrm{H}_{2} \mathrm{O}_{2}\right)$ in plants (Misra \& Gupta 2006; Kholová et al 2010). Lipid peroxidation, induced by ROS, is also important in membrane deterioration (Demiral \& Turkan 2005). Thus, cell membrane stability has widely been utilized to differentiate salt-tolerant and salt-sensitive cultivars (Meloni et al 2003). Salinity promotes oxidative stress and plants with high constitutive and induced antioxidant enzymes have better tolerance to damage (Parida $\&$ Das 2005). The generation of ROS is limited or scavenged by antioxidant enzymes such as superoxide dismutase (SOD), guaiacol peroxidase (POD), ascorbate peroxidase (APX) and catalase (CAT) (Foyer \& Noctor 2003). Comparison of the responses of cultivars and/or related species that exhibit differential sensitivity to salt stress showed a correlation between salt tolerance and increased activity of the antioxidant system (Neto et al 2006; Athar et al 2008).

Barley is considered highly salt tolerant and can grow in the areas with elevated salt contents (Royo \& Aragüés 1999). Existence of differences in salt tolerance not only amongst different species, but also within certain species (Munns \& Tester 2008) offers an opportunity for identifying and developing salt-tolerant genotypes. The aim of this study is to evaluate the comparative effects of different concentrations of $\mathrm{NaCl}$ salinity on growth, chlorophyll biosynthesis, proline content, lipid peroxidation and SOD, POD, APX and CAT activity of salt-tolerant (Avc1-2002) and saltsensitive (Tokak 157/37) barley cultivars at early seedling stage. Comparison of these parameters in the present barley cultivars grown in Turkey may 
be helpful in developing a better understanding and provide additional information on the mechanisms of salt tolerance.

\section{Material and Methods}

\subsection{Plant materials, growth and treatment conditions}

Based on our preliminary studies, two barley cultivars (relatively salt-tolerant Avc1-2002 and salt-sensitive Tokak 157/37) were chosen from twelve barley cultivars for their different salt tolerance at early seedling stage (Yıldız \& Terzi 2011). Healthy uniform seeds of barley cultivars were sterilized in $2 \%(\mathrm{w} / \mathrm{v})$ sodium hypochlorite $(\mathrm{NaOCl})$ solution for $20 \mathrm{~min}$. Seeds were germinated at $25^{\circ} \mathrm{C}$ in dark on two filter papers in germination cups wetted with distilled water for three days. Three-day-old etiolated seedlings were grown in a jar including half strength Hewitt's nutrient solution at a constant temperature regime of $25 \pm 1{ }^{\circ} \mathrm{C}, 60 \%$ humidity and at 13.000 lux light intensity, $12 \mathrm{~h}$ photoperiod for $24 \mathrm{~h}$. Four-dayold seedlings were grown hydroponically in half strength Hewitt's nutrient solutions without $\mathrm{NaCl}$ or with 100,200 and $300 \mathrm{mM} \mathrm{NaCl}$ for six days. At the end of $10^{\text {th }}$ day, the first leaves of control and $\mathrm{NaCl}$-treated barley seedlings were sampled for physiological and biochemical analyses.

\subsection{Growth parameter}

$\mathrm{NaCl}$ phytotoxicity was assessed in the terms of shoot and root dry weights for the treated and untreated control seedlings. A total of 10 plants from each treatment were sampled randomly at the seventh day of $\mathrm{NaCl}$ treatment, and shoots and roots were separated. The shoot and root tissues were dried in an oven at $80^{\circ} \mathrm{C}$ for $48 \mathrm{~h}$. The dried samples were weighed immediately after the removal from the oven until biomass became stable. The dry weights were expressed as percentage of control.

\subsection{Estimation of ALAD activity}

The extraction of $\delta$-aminolevulinic acid dehydratase (ALAD) from the excised leaf tissue was carried out according to Naito et al (1980) as described in Vajpayee et al (2000). Fresh leaf samples (1 g) from control and $\mathrm{NaCl}$-treated seedlings were homogenized in $0.05 \mathrm{M}$ Tris- $\mathrm{HCl}$ buffer $(\mathrm{pH}$ 8.2) containing $0.1 \mathrm{mM}$ dithiotheritol (DTT, $0.5 \mathrm{~mL} \mathrm{~g}^{-1}$ FW) in a pre-chilled mortar. The homogenate was filtered through four layers of cheese cloth. The filtrate was centrifuged at $10000 \times g$ for $1 \mathrm{~h}$ at $4^{\circ} \mathrm{C}$ and the resultant supernatant was assayed for ALAD activity according to the method of Schneider (1970). One $\mathrm{mL}$ of supernatant was mixed with $0.27 \mathrm{~mL}$ of $1 \mathrm{mg} \mathrm{mL}^{-1} \delta$-aminolevulinic acid (ALA) and $1.35 \mathrm{~mL}$ of $0.05 \mathrm{M}$ Tris- $\mathrm{HCl}$ buffer $(\mathrm{pH} 8.2)$ containing $0.1 \mathrm{mM}$ DTT and $0.08 \mathrm{~mL}$ of $0.2 \mathrm{M}$ $\mathrm{MgCl}_{2}$. The reaction mixture was incubated at $37^{\circ} \mathrm{C}$ for $2.5 \mathrm{~h}$. The reaction was terminated by addition of $0.3 \mathrm{~mL}$ of $3.0 \mathrm{M}$ trichloroacetic acid. After cooling, samples were centrifuged at $2000 \times g$ for $10 \mathrm{~min}$. One $\mathrm{mL}$ of supernatant was mixed with an equal amount of Ehrlich's reagent, and absorbance of the mixture was determined at $555 \mathrm{~nm}$ after 10 min against zero time blank. The concentration of porphobilinogen (PBG) was calculated according to Mauzerall and Granick (1956) and the ALAD activity is expressed as nmol PBG $2.5 \mathrm{~h}^{-1} \mathrm{mg}^{-1}$ protein at $37^{\circ} \mathrm{C}$. In addition, protein concentration of leaf crude extract was determined according to the method of Bradford (1976).

\subsection{Chlorophyll and carotenoid pigments content}

Total chlorophyll (Chl $a+b)$ and carotenoid pigments in the leaf tissues $(100 \mathrm{mg})$ of control and $\mathrm{NaCl}$-treated seedlings were extracted in methanol and determined by the method of Wellburn (1994).

\subsection{Proline content}

Proline content of leaf tissues was estimated spectrophotometrically following the ninhydrin method described by Bates et al (1973) with minor modification. Powdered frozen tissues $(200$ $\mathrm{mg}$ ) were homogenized in $3 \%$ of sulphosalicylic acid to precipitate protein. Samples were mixed, centrifuged at $8000 \times g$ for $15 \mathrm{~min}$, and the supernatants were treated with glacial acetic acid and ninhydrin reagent $[3 \%(\mathrm{w} / \mathrm{v})$ ninhydrin in $60 \%$ 
(v/v) $6 \mathrm{M}$ phosphoric acid] for $1 \mathrm{~h}$ at $90^{\circ} \mathrm{C}$. After icecooling, the products were extracted with toluene by vortex mixing, and then the absorbance of the upper (toluene) phase was determined at $520 \mathrm{~nm}$ against a zero time blank. Proline concentrations were calculated using proline standards $(0-100 \mu \mathrm{g}$ $\mathrm{mL}^{-1}$ ) in identical manner.

\subsection{Determination of lipid peroxidation}

The level of lipid peroxidation was measured by estimating malondialdehyde (MDA), a decomposition product of peroxidized polyunsaturated fatty acid component of membrane lipids, using thiobarbituric acid (TBA) as the reactive material (Heath \& Packer 1968). The leaf tissues $(250 \mathrm{mg})$ were homogenized with $5 \%(\mathrm{w} / \mathrm{v})$ trichloroacetic acid (TCA) followed by centrifugation at $15000 \times g$ for $5 \mathrm{~min}$. For each 250 $\mathrm{mL}$ aliquot, $1 \mathrm{~mL}$ of $20 \%(\mathrm{w} / \mathrm{v})$ TCA containing $0.5 \%(\mathrm{w} / \mathrm{v})$ TBA was added. The mixture was heated at $95^{\circ} \mathrm{C}$ for $30 \mathrm{~min}$ and then cooled in an ice bath to stop the reaction. The tubes were centrifuged at $10000 \times g$ for $10 \mathrm{~min}$, and the absorbance of the supernatant at 532 and $600 \mathrm{~nm}$ was recorded. After subtracting the nonspecific turbidity at $600 \mathrm{~nm}$, the MDA concentration was determined by its molar extinction coefficient $\left(155 \mathrm{mM}^{-1} \mathrm{~cm}^{-1}\right)$ (Heath and Packer 1968).

\subsection{Extraction and assay of antioxidative enzymes}

The leaf tissues $(200 \mathrm{mg}$ ) were homogenized in $2 \mathrm{~mL}$ of $100 \mathrm{mM}$ potassium phosphate buffer, $\mathrm{pH} 6.8$ containing $1 \mathrm{mM}$ of EDTA and $1 \%(\mathrm{w} / \mathrm{v})$ polyvinylpyrrolidone (PVP). The extract was then centrifuged at $4^{\circ} \mathrm{C}$ for $15 \mathrm{~min}$ at $12.000 \times \mathrm{g}$ in a cooled centrifuge. This supernatant was used to measure the activities of superoxide dismutase (SOD), guaiacol peroxidase (POD), ascorbate peroxidase (APX) and catalase (CAT). The protein concentration of leaf crude extract was determined according to Bradford (1976). Activity of SOD was assayed by using the photochemical nitro blue tetrazolium (NBT) method. The assay was performed in terms of SOD's ability to inhibit reduction of NBT to form formazan by superoxide radical as described by
Beauchamp and Fridovich (1971). Activity of POD was determined at $25^{\circ} \mathrm{C}$ with guaiacol (Bergmeyer 1974). Activity of APX was measured by following the rate of hydrogen peroxide-dependent oxidation of ascorbic acid (Nakano \& Asada 1981). Finally, the activity of CAT was assayed following $\mathrm{H}_{2} \mathrm{O}_{2}$ decomposition according to Aebi (1984).

\subsection{Statistical analyses}

All the experiments were repeated at twice with three replicates $(n=6)$. Statistical analyses were performed with the statistical software package SPSS, version 16.0. The means were compared by the Duncan's test at a significance level of $P$ $<0.05$.

\section{Results and Discussion}

\subsection{Effect of $\mathrm{NaCl}$ on growth}

In many crop species, salt tolerance is reported to be a developmental regulated and stage specific phenomenon (Ashraf \& Harris 2004). Shoot and root growth inhibition are the most important indices of salt tolerance (Munns 2002). In order to evaluate salt tolerance of salt-tolerant Avc1-2002 and salt-sensitive Tokak 157/37 barley cultivars at early seedling stage, dry weights of shoots and roots (percent of control) were tested under the effect of $\mathrm{NaCl}$ salinity. Salinity stress significantly reduced shoot and root dry weights of both barley cultivars (Figure 1A \& B).

However, the decrease in shoot and root dry weights of Tokak 157/37 was significantly higher than that of Avc1-2002 under salt stress. Biomass differences among plant cultivars under saline conditions are important in determining tolerance (Bağc1 et al 2003). Similar to our results dry weights of shoots and roots were less affected in many salt-tolerant cultivars such as wheat (Zheng et al 2008) and canola (Ashraf \& Ali 2008). In the present study, shoot dry weights of both cultivars was affected more than root dry weights by salinity and this led to higher root/shoot ratio (Figure 1C). In this sense, no the root/shoot ratio generally changed in Avc1-2002, while it increased in Tokak 
$157 / 37$ with increasing $\mathrm{NaCl}$ concentration. It is suggested that the root/shoot dry weight ratio could be correlated to differences in salt tolerance of barley cultivars. Similar result was reported by Dasgan et al (2002).
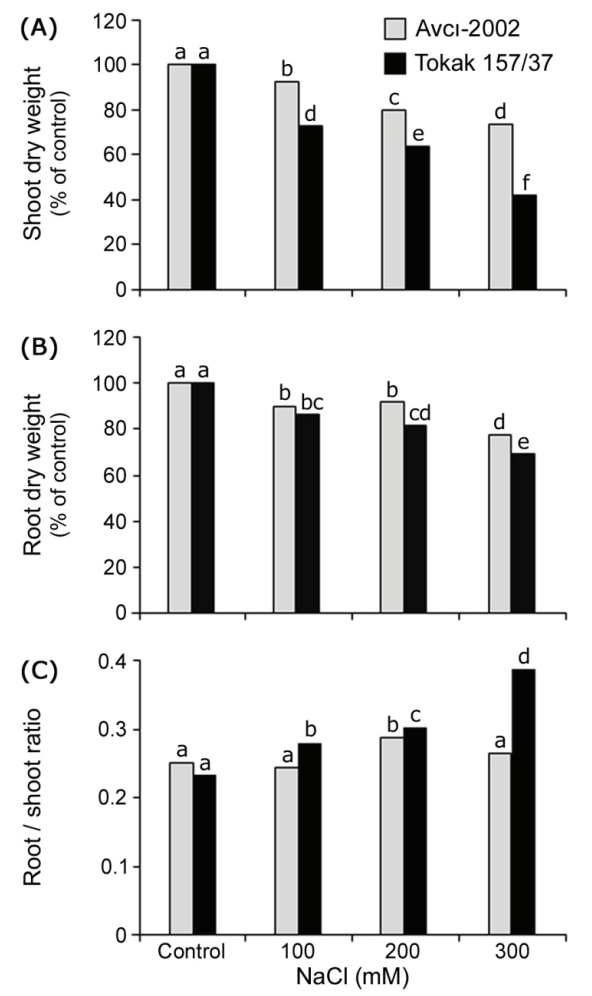

Figure 1- Effect of $\mathrm{NaCl}$ salinity on shoot $(\mathrm{A})$ and $\operatorname{root}(B)$ dry weights and root/shoot ratios (C) of salttolerant Avci-2002 and salt-sensitive Tokak 157/37 barley cultivars. Values without a common letter are statistically different according to Duncan's multiple range test $(P<\mathbf{0 . 0 5})$

Şekil 1- Tuza-toleransl Avcl-2002 ve tuza-hassas Tokak 157/37 arpa çeşitlerinin gövde (A) ve kök (B) kuru ağırlıklarl ve kök/gövde oranları (C) üzerine $\mathrm{NaCl}$ tuzluluğunun etkisi. Ortak harfe sahip olmayan değerler Duncan çoklu karşılaştırma testine göre istatistiki olarak önemlidir $(P<0.05)$

\subsection{Effect of $\mathrm{NaCl}$ on $A L A D$ and pigments content}

To study the effect of $\mathrm{NaCl}$ on intermediate step of chlorophyll biosynthesis, we analyzed ALAD activity. Although ALAD activity of both cultivars decreased at all $\mathrm{NaCl}$ concentrations studied (except for $100 \mathrm{mM} \mathrm{NaCl}$ in Avc1-2002); the activity was increased at $300 \mathrm{mM} \mathrm{NaCl}$ compared to other $\mathrm{NaCl}$ concentrations (Figure 2A).
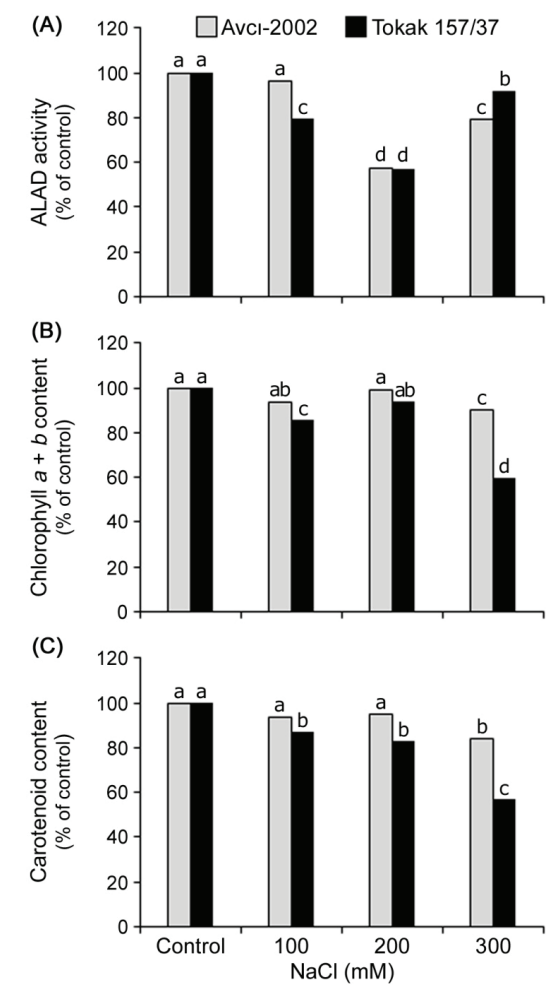

Figure 2- Effect of $\mathrm{NaCl}$ salinity on ALAD activity (A), total chlorophyll (B) and carotenoid (C) contents in leaf tissues of salt-tolerant Avcl-2002 and salt-sensitive Tokak $157 / 37$ barley cultivars. Values without a common letter are statistically different according to Duncan's multiple range test $(P<\mathbf{0 . 0 5})$

Şekil 2- Tuza-toleransll Avcl-2002 ve tuza-hassas Tokak 157/37 arpa çeşitlerinin yaprak dokularında ALAD aktivitesi (A), toplam klorofil (B) ve karotenoid (C) içerikleri üzerine $\mathrm{NaCl}$ tuzluluğunun etkisi. Ortak harfe sahip olmayan değerler Duncan çoklu karşılaştırma testine göre istatistiki olarak önemlidir $(P<0.05)$

At $300 \mathrm{mM} \mathrm{NaCl}$, altered ALAD activity did not accompany with reduced chlorophyll content. In light of this knowledge, the ALAD activities of Avc1- 
2002 decreased at 100 and $200 \mathrm{mM} \mathrm{NaCl}$ compared to the controls, although chlorophyll pigments content did not alter. It is suggested that ALAD was not the limiting factor for the transformation of $\delta$-aminolevulinic acid (ALA) to porphobilinogen in the chlorophyll biosynthesis. Chlorophyll contents have been suggested as one of the parameters of salt tolerance in crop plants (Srivastava et al 1988). In our study, salt-sensitive Tokak $157 / 37$ showed significantly higher decline in total chlorophyll content than salt-tolerant Avc1-2002 under $\mathrm{NaCl}$ salinity that reflects Avc1-2002 cultivar's tolerance (Figure 2B). Sairam et al (2005) observed higher chlorophyll degradation in salt-sensitive wheat cultivars as compared to tolerant cultivars. The decrease in chlorophyll content may be due to an increase of chlorophyll degradation or to a decrease of chlorophyll biosynthesis (Santos 2004). On the other hand, salt-tolerant Avc1-2002 retained higher carotenoid content than salt-sensitive Tokak 157/37 under salt stress (Figure 2C). Similar results were found in leaves of salt-tolerant cultivars of maize (Kholová et al 2010). Carotenoids are responsible for quenching of singlet oxygen (Knox \& Dodge 1985), hence their comparative levels in a genotype may determine its relative salt tolerance (Kholová et al 2010).

\subsection{Effect of $\mathrm{NaCl}$ on proline content}

A positive correlation between magnitude of free proline accumulation and salt tolerance has been suggested as an index for determining salt tolerance potentials between cultivars (Misra \& Gupta 2005). The magnitude of increase in free proline accumulation was higher in the tolerant cultivars than in the sensitive ones (Misra \& Gupta 2005; Kholová et al 2010). However, some researchers reported that proline accumulation cannot be used as a sole criterion for salt tolerance (Moradi \& Ismail 2007). In the present study, the proline contents increased significantly in the leaf tissues of Avc1-2002 and Tokak 157/37 barley cultivars under salinity (Figure 3).

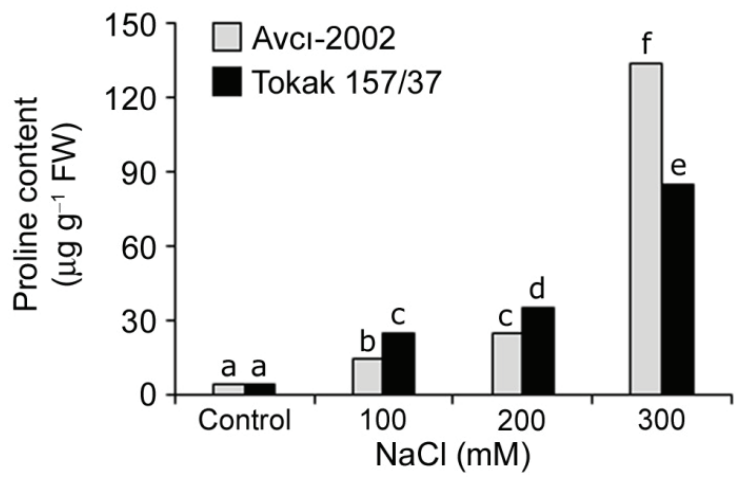

Figure 3- Effect of $\mathrm{NaCl}$ salinity on proline content in leaf tissues of salt-tolerant Avcr-2002 and saltsensitive Tokak $157 / 37$ barley cultivars. Values without a common letter are statistically different according to Duncan's multiple range test $(P<\mathbf{0 . 0 5})$

Şekil 3-Tuza-toleransli Avcl-2002 ve tuza-hassas Tokak 157/37 arpa çeşitlerinin yaprak dokularında prolin içeriği üzerine $\mathrm{NaCl}$ tuzluluğunun etkisi. Ortak harfe sahip olmayan değerler Duncan çoklu karşılaştırma testine göre istatistiki olarak önemlidir $(P<0.05)$

At $300 \mathrm{mM} \mathrm{NaCl}$, the proline contents in the leaf tissues of salt-tolerant Avc1-2002 and saltsensitive Tokak 157/37 increased 31- and 20-fold, respectively. According to our results, there was a positive correlation between proline accumulation and salt tolerance of barley cultivars. Among various compatible solutes, proline is the only molecule that can act as free radical scavenger and antioxidant activity (Sharma \& Dietz 2006). Therefore, proline is able to stabilize proteins, DNA as well as membranes (Matysik et al 2002). It is suggested that the higher proline concentration in salt-tolerant Avc1-2002 under salt stress may help maintain structure and function of cellular macromolecules.

\subsection{Effect of $\mathrm{NaCl}$ on $\mathrm{MDA}$ content}

Lipid peroxidation measured as is produced when polyunsaturated fatty acids in the membrane undergo oxidation by the accumulation of free oxygen radicals. The level of lipid peroxidation (the amount of malondialdehyde, MDA) has been consider an indicator of salt-induced oxidation in cell membranes and a tool for determining salt 
tolerance in plants (Hernández \& Almansa 2002). The results reported here show that salt-sensitive Tokak 157/37 has a higher MDA content than salt-tolerant Avc1-2002 in all $\mathrm{NaCl}$ concentrations, indicating less oxidative damage in Avc1-2002 compared to Tokak 157/37 (Figure 4). At the highest $\mathrm{NaCl}$ concentration, we observed the low MDA levels in both barley cultivars, suggested that high proline content probably plays a functional role in mitigating the effects of salt stress on lipid peroxidation. Salt-tolerant barley, wheat and rice (Liang et al 2003; Sairam et al 2005; Moradi \& Ismail 2007) had lower levels of lipid peroxidation which is important sign of higher oxidative damage limiting capacity under salinity.

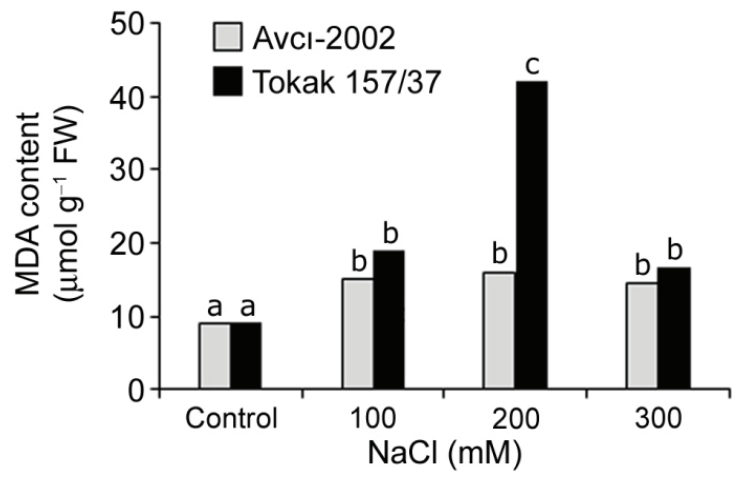

Figure 4- Effect of $\mathrm{NaCl}$ salinity on malondialdehyde (MDA) content in leaf tissues of salt-tolerant Avcl-2002 and salt-sensitive Tokak 157/37 barley cultivars. Values without a common letter are statistically different according to Duncan's multiple range test $(P<0.05)$

Şekil 4- Tuza-toleranslı Avcl-2002 ve tuza-hassas Tokak 157/37 arpa çeşitlerinin yaprak dokularında malondialdehit (MDA) içeriği üzerine $\mathrm{NaCl}$ tuzluluğunun etkisi. Ortak harfe sahip olmayan değerler Duncan çoklu karşılaştırma testine göre istatistiki olarak önemlidir $(P<0.05)$

\subsection{Effect of $\mathrm{NaCl}$ on antioxidant enzymes activity}

In plants, salinity induces oxidative stress by generating reactive oxygen species (ROS) such as $\mathrm{H}_{2} \mathrm{O}_{2}, \mathrm{O}_{2}{ }^{--}, \cdot \mathrm{OH}$ and ${ }^{1} \mathrm{O}_{2}$ (Misra \& Gupta 2006). Plants possess antioxidant enzymes as well as antioxidant compounds to scavenge these ROS, and antioxidant capacity of plants is directly related to their salt tolerance. Our results show that salinity stress increased the activities of SOD, POD, APX and CAT in the leaf tissues of salt-tolerant Avc12002 and salt-sensitive Tokak 157/37 (Fig 5A-D).

The increase in SOD activity of Tokak 157/37 was greater than in Avc1-2002 at 200 and 300 mM $\mathrm{NaCl}$ compared to their controls. Higher POD activity was observed in Avc1-2002 than in Tokak $157 / 37$ at all $\mathrm{NaCl}$ concentrations. Higher CAT activity was observed in Tokak 157/37 than in Avc12002 at 200 and $300 \mathrm{mM} \mathrm{NaCl}$. The increase in APX activity of Avc1-2002 was greater than Tokak $157 / 37$ at all $\mathrm{NaCl}$ concentrations compared to the control. As a result, Avc1-2002 had relatively lower SOD and CAT activities and higher POD and APX activities than Tokak 157/37. Previous studies reported that salt-tolerant cultivars generally show higher activity of these antioxidant enzymes as compared to salt-sensitive ones (Zheng et al 2008; Ashraf \& Ali 2008; Kholová et al 2010). However, the results reported here show that high POD and APX activities may possibly play a significant role in imparting salt tolerance in Avc1-2002 under increasing salinity stress. $\mathrm{O}_{2}{ }^{--}$and $\mathrm{H}_{2} \mathrm{O}_{2}$ are toxic ROS, having deleterious effects in plant tissue. SOD catalyzes the dismutation of toxic $\mathrm{O}_{2}{ }^{\cdot-}$ to $\mathrm{H}_{2} \mathrm{O}_{2}$ (Salin 1988). The salinity induced enhancement of POD, APX and CAT activities in salt-stressed plants indicates that these cells have a higher capacity for the decomposition of $\mathrm{H}_{2} \mathrm{O}_{2}$ generated by SOD (Meloni et al 2003). It is noteworthy that salt-induced SOD activity in the leaves was accompanied by a greater increase in POD and APX activities in Avc1-2002 than in Tokak 157/37, indicating that the $\mathrm{H}_{2} \mathrm{O}_{2}$ scavenging mechanism was more effective in Avc1-2002. Similar results related with antioxidative system activity were also reported by other researchers (Liang et al 2003; Neto et al 2006). 

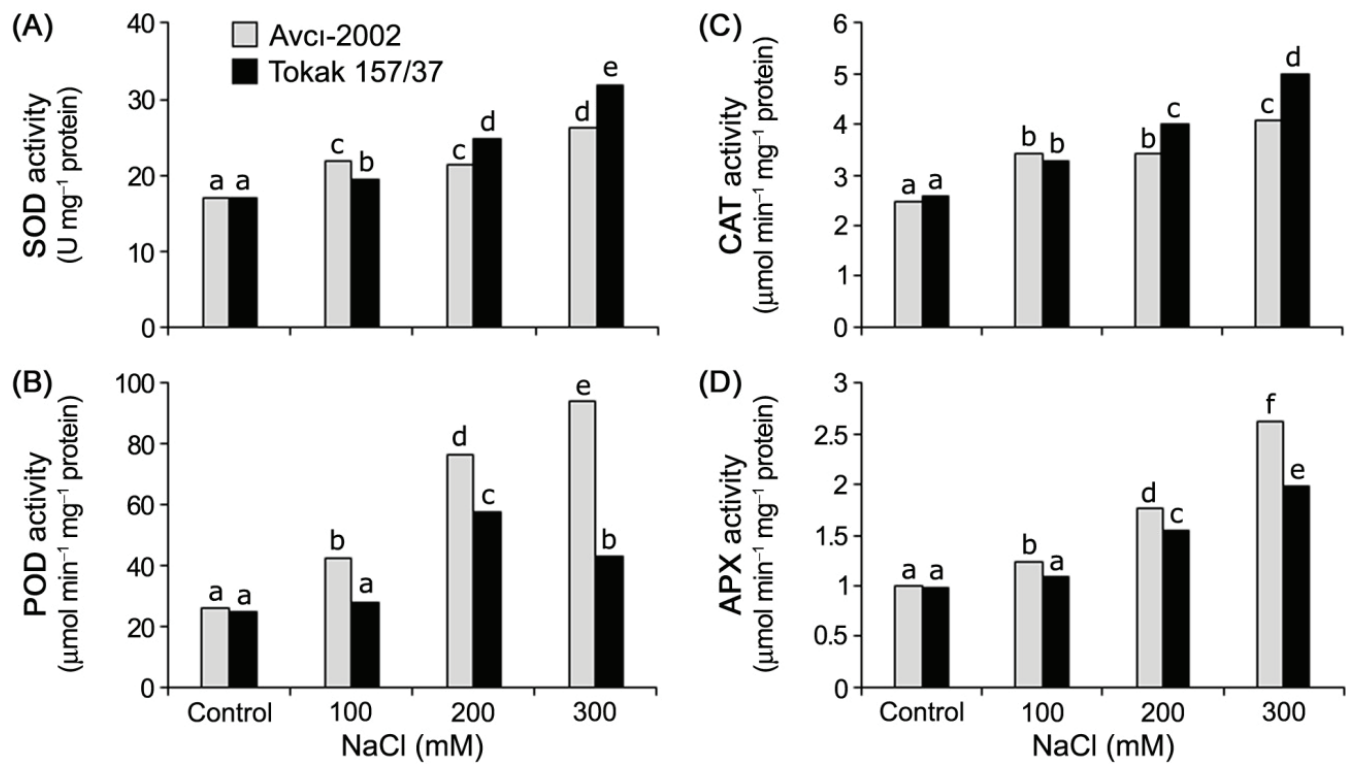

Figure 5- Effect of NaCl salinity on SOD (A), POD (B), CAT (C) and APX (D) activity in leaf tissues of salttolerant Avcı-2002 and salt-sensitive Tokak 157/37 barley cultivars. Values without a common letter are statistically different according to Duncan's multiple range test $(P<\mathbf{0 . 0 5})$

Şekil 5- Tuza-toleranslı Avcl-2002 ve tuza-hassas Tokak 157/37 arpa çeşitlerinin yaprak dokularında SOD (A), POD (B), CAT (C) ve APX (D) aktivitesi üzerine NaCl tuzluluğunun etkisi. Ortak harfe sahip olmayan değerler Duncan çoklu karşılaştırma testine göre istatistiki olarak önemlidir $(P<0.05)$

\section{Conclusions}

This study showed that the differences in growth, chlorophyll and carotenoid contents, proline content, lipid peroxidation and SOD, POD, APX and CAT activities in the two barley cultivars could be ascribed to the difference in mechanisms underlying oxidative stress injury and subsequent tolerance to salinity. However, ALAD activity was not found to be an effective determinant of salt tolerance between the barley cultivars examined. Avc1-2002, a relatively salt-tolerant cultivar, exhibits a better protection mechanism against oxidative damage and lipid peroxidation by maintaining higher pigments content, proline content and activities of POD and APX than Tokak 157/37, a relatively salt-sensitive cultivar. Higher free radical scavenging capacity and more efficient protection mechanism in Avc12002 against salt stress as revealed by the lower lipid peroxidation level. The marked difference in the activities of POD and APX, and proline contents in tolerant and susceptible genotypes suggest that these play an important role in the overall mechanism of salinity stress tolerance in barley.

\section{Acknowledgements}

The authors wish to thank Afyon Kocatepe University Scientific Research Project Coordination Unit (Project no: 06.FENED.01) for financial support.

\section{References}

Aebi H (1984). Catalase in vitro. Methods in Enzymology 105: $121-126$

Ashraf M \& Harris P J C (2004). Potential biochemical indicators of salinity tolerance in plants. Plant Science 166: 3-16 
Ashraf M \& Ali Q (2008). Relative membrane permeability and activities of some antioxidant enzymes as the key determinants of salt tolerance in canola (Brassica napus L.). Environmental and Experimental Botany 63: $266-273$

Athar H, Khan A \& Ashraf M (2008). Exogenously applied ascorbic acid alleviates salt-induced oxidative stress in wheat. Environmental and Experimental Botany 3: 224-231

Bağc1 S A, Ekiz H \& Y1lmaz A (2003). Determination of the salt tolerance of some barley genotypes and the characteristics affecting tolerance. Turkish Journal of Agriculture and Forestry 27: 253-260

Bates L S, Waldren R P \& Teare I D (1973). Rapid determination of proline for water-stress studies. Plant and Soil 39: 205-207

Beauchamp C \& Fridovich I (1971). Superoxide dismutase: improved assay and an assay applicable to acrylamide gels. Analytical Biochemistry 44: 276-287

Bergmeyer H U (1974). Methods of Enzymatic Analysis. New York, Academic Press

Bradford M M (1976). A rapid and sensitive method for the quantitation of microgram quantities of proteins utilizing the principle of protein dye binding. Analytical Biochemistry 72: 248-254

Dasgan H Y, Aktas H, Abak K \& Cakmak I (2002). Determination of screening techniques to salinity tolerance in tomatoes and investigation of genotype responses. Plant Science 163: 695-703

Demiral T \& Turkan I (2005). Comparative lipid peroxidation, antioxidant defense systems and proline content in roots of two rice cultivars differing in salt tolerance. Environmental and Experimental Botany 53: $247-257$

Foyer C H \& Noctor G (2003). Redox sensing and signaling associated with reactive oxygen in chloroplasts, peroxisomes and mitochondria. Physiologia Plantarum 119: 355-364

Heath R L \& Packer L (1968). Photoperoxidation in isolated chloroplasts. Archives of Biochemistry and Biophysics 125: 189-198

Hernández J A \& Almansa M S (2002). Short-term effects of salt stress on antioxidant systems and leaf water relations of pea leaves. Physiologia Plantarum 115: 251-257

Kholová J, Sairam R K \& Meena R C (2010). Osmolytes and metal ions accumulation, oxidative stress and antioxidant enzymes activity as determinants of salinity stress tolerance in maize genotypes. Acta Physiologiae Plantarum 32: 477-486

Knox J P \& Dodge A O (1985). Singlet oxygen and plants. Phytochemistry 24: 889-896

Liang Y, Chen Q, Liu Q, Zhang W \& Ding R (2003). Exogenous silicon ( $\mathrm{Si}$ ) increases antioxidant enzyme activity and reduces lipid peroxidation in roots of salt-stressed barley (Hordeum vulgare L.). Journal of Plant Physiology 160: 1157-1164

Matysik J A, Bhalu B \& Mohanty P (2002). Molecular mechanisms of quenching of reactive oxygen species by proline under stress in plants. Current Science 82: 525-532

Mauzerall D \& Granick S (1956). The occurrence and accumulation of $\delta$-aminolevulinic acid and porphobilinogen in urine. Journal of Biological Chemistry 219: 435-446

Meloni D A, Oliva M A, Martinez C A \& Cambraia J (2003). Photosynthesis and activity of superoxide dismutase, peroxidase and glutathione reductase in cotton under salt stress. Environmental and Experimental Botany 49: 69-76

Misra N \& Gupta A K (2005). Effect of salt stress on proline metabolism in two high yielding genotypes of green gram. Plant Science 169: 331-339

Misra N \& Gupta A K (2006). Effect of salinity and different nitrogen sources on the activity of antioxidant enzymes and indole alkaloid content in Catharanthus roseus seedlings. Journal of Plant Physiology 163: $11-18$

Moradi F \& Ismail A M (2007). Responses of photosynthesis, chlorophyll fluorescence and ROSscavenging systems to salt stress during seedling and reproductive stages in rice. Annals of Botany 99: 1161-1173

Munns R (2002). Comparative physiology of salt and water stress. Plant Cell and Environment 25: 239-250

Munns R \& Tester M (2008). Mechanisms of salinity tolerance. Annual Reviews of Plant Biology 59: 651681

Naito K, Ebato T, Endo Y \& Shimizu S (1980). Effect of benzyladenine on $\delta$-aminolevulinic acid synthetic ability and $\delta$-aminolevulinic acid dehydratase: differential responses to benzyladenine according to leaf age. Zeitschrift für Pflanzenphysiologie 96: 95102 
Nakano Y \& Asada K (1981). Hydrogen peroxide is scavenged by ascorbate specific peroxidase in spinach chloroplasts. Physiologia Plantarum 115: 393-400

Neto A D A, Prisco J T, Enéas-Filho J, Abreu C E B \& Gomes-Filho E (2006). Effect of salt stress on antioxidative enzymes and lipid peroxidation in leaves and roots of salt-tolerant and salt-sensitive maize genotypes. Environmental and Experimental Botany 56: 87-94

Parida A K \& Das A B (2005). Salt tolerance and salinity effects on plants: a review. Ecotoxicology and Environmental Safety 60: 324-349

Ramanjulu S \& Sudhakar C (2001). Alliviation of $\mathrm{NaCl}$ salinity stress by calcium is partly related to the increased proline accumulation in mulberry (Morus alba L.) callus. Journal of Plant Biology 28: 203-206

Royo A \& Aragüés R (1999). Salinity-yield response functions of barley genotypes assessed with a triple line source sprinkler system. Plant and Soil 209: 9-20

Sairam R K, Srivastava G C, Agarwal S \& Meena R C (2005). Differences in antioxidant activity in response to salinity stress in tolerant and susceptible wheat genotypes. Biologia Plantarum 49: 85-91

Salin M L (1988). Toxic oxygen species and protective system of the chloroplasts. Physiologia Plantarum 72: 681-689

Santos C V (2004). Regulation of chlorophyll biosynthesis and degradation by salt stress in sunflower leaves. Scientia Horticulturae 103: 93-99
Scheneider H A W (1970). Activities and properties of $\delta$-aminolevulinic acid dehydratase in greening tissue cultures of Nicotiana tabacum cv. Samsum. Zeitschrift für Pflanzenphysiologie 62: 133-145

Sharma S S \& Dietz K J (2006). The significance of amino acids and amino acid-derived molecules in plant responses and adaptation to heavy metal stress. Journal of Experimental Botany 57: 711-726

Srivastava T P, Gupta S C, Lal P, Muralia P N \& Kumar A (1988). Effect of salt stress on physiological and biochemical parameters of wheat. Annals of Arid Zone 27: 197-204

Vajpayee P, Tripathi R D, Rai U N, Ali M B \& Singh S $\mathrm{N}$ (2000). Chromium (VI) accumulation reduces chlorophyll biosynthesis, nitrate reductase activity and protein content in Nymphaea alba L. Chemosphere 41: $1075-1082$

Wellburn A R (1994). The spectral determination of chlorophylls a and b, as well as total carotenoids, using various solvents with spectrophotometers of different resolution. Journal of Plant Physiology 144: 307-313

Y1ldı M \& Terzi H (2011). Determination of early seedling stage salt tolerance in some barley cultivars grown in Turkey. Tarım Bilimleri Dergisi-Journal of Agriculture Sciences 17: 1-9

Zheng Y, Jia A, Ning T, Xu J, Li Z \& Jiang G (2008). Potassium nitrate application alleviates sodium chloride stress in winter wheat cultivars differing in salt tolerance. Journal of Plant Physiology 165: 1455-1465 